\title{
CLAIM OF TITLE IN ȦDVERSE POSSESSION
}

\author{
Hengy Winthrop Batrantine \\ University of Illinois
}

\section{BASIS AND EXTENT OF REQUIREMENT.}

The adverse possession which is requisite to establish title and bar the rights of the ousted owner must, it is said, include five elements. It must be (I) hostile or adverse, (2) actual (as to part of the land), (3) visible, notorious and exclusive, (4) continuous for the statutory period, and (5) under claim or color of title. ${ }^{1}$

It is almost universally held that the basis of an adverse possession is a claim of title or right. No title can be acquired against the true owner by merely squatting on real estate. ${ }^{2}$ Color of title is not necessary, but the possession must evidence some claim inconsistent with that of the true owner. A few cases, however, seem to declare that claim of title is not essential." Why should "claim of title" be an essential element? In most statutes of limitation there is no mention of claim of title. By what authority, then, do courts superadd such a requirement?

The explanation is that the title acquired under the statute results from the joint operation of the statute and the common law rules as to possession. The owner must be ousted and put to his action before the statute begins to run against him. The operation of the statute is sometimes called "negative prescription". There is no "statutory conveyance" to the man in possession. The statute deals with the remedies of the claimant out of possession. The remedies and title of the ousted owner are extinguished rather than transferred by the statute."

${ }^{1}$ Zirngibl v. Calumet Dock Co. (1895) I57 Ill., 430, 447. Stowell v. Lynch (I9I5) 269 Ill. 437,443 ; IIO N. E. 5 I. This enumeration does not represent the most careful analysis, as there is some duplication or overlapping between these elements. Number (3) enumerates some of the physical characteristics of number (2), actual possession. Number (I) and number (5), relating to the intent required, come to much the same thing.

${ }^{2}$ Harvey v. Tyler (1864, U. S.) 2 Wall. 328; Jasperson v. Scharmikow (1907, C. C. A. 9th) 150 Fed. 571,15 L. R. A. (N. S.) II78.

Steverns v. Smoker (rgIr) 84 Conn. 569, 80 Atl. 788; Carney v. Hennessey (IgOr) 74 Conn. 107, 49 Atl. 910; Illinois Steel Compary v. Bilot (190r) 109 Wis. 418,84 N. W. 855,85 N. W. 402 . See also Illirois Steel Co. v. Paczocha (Igog) I39 Wis. 23, 35, Irg N. W. 550; Illinois Steel Co. v. Budzisz (1900) 106 Wis. 499, $509,52 \mathrm{r}, 8 \mathrm{I}$ N. W. 1027.

A. C. Meredith, A Paradox of Sugdern's (19r8) 34 L. Quarr. Rev. 253; Dalton v. Fitzgerald [1897] 2 Ch. 86, 90; In re Atkinson and Horsell's Contract (C. A.) [rgra] 2 Ch. 1, 9. See also article by the writer, Title by Adverse Possession (1918, December) 32 Harv. L. Rev. 
The indirect effect of the statute is to quiet and set free the possessory title of the adverse holder. The claim of title measures the extent of the possessory title so established. If there is no claim of title there is nothing to be quieted. As Justice Story says in Ricard v. Williams:

"Possession per se evidences no more than the mere fact of present occupation by right, and that possession is just as consistent with a present interest under a lease for years or for life, as in fee."

What is the quality and extent of the interest claimed by the party is shown by his declarations and acts while in possession. If he claims only an estate for life, the law will not, upon the mere fact of possession, adjudge him to be in under a higher right or a larger estate. The interest acquired by possession is, therefore, measured by the claim set up. As Justice Story points out in the case last cited:

"If the party claim only a limited estate and not a fee, the law will not, contrary to his intentions, enlarge it to a fee."

There can indeed hardly be such a thing as possession in law, entitling one to the possessory remedies, without a claim of title, at least to some limited or temporary proprietary interest. Possession in itself implies some such claim. ${ }^{\circ}$ It need not, however, be hostile to or inconsistent with the title of others. A tenant at will or a precarious bailee has possession adverse to the world, and to some extent independent of the owner, though for most purposes it is also the possession of the owner. The family or servants, the guests or lodgers of a householder do not have possession, even during the absence of the owner, as there is no claim of title or interest on their part even for the time being." Their occupation is entirely subordinate to and in the name of the owner.

A servant or agent is denied legal possession because his acts are the acts of the owner, and he does not make any independent claim of title, although he may have the physical relation to the object which, in general, characterizes possession. ${ }^{8}$ By an anomaly of the common law, a subservient bailee like a depositary for storage, who holds chattels entirely subject to the orders of the owner, is yet regarded as having temporary legal possession, rather than mere custody. In

(r822, U. S.) 7 Wheat. 59.

- Littledale v. Liverpool College (C. A.) [1900] I Ch. 19, 23; Fort Dearborn Lodge v. Klein (I885) II5 Ill. I77, 182, 183, 3 N. E. 272. Compare, however, Prof. H. T. Terry, Possession (I9I8) I3 ILI. L. Rev., 314, 320; Prof. Joseph Bingham, The Nature and Importance of Legal Possession (I9I5) I3 MICE. L. REv. 549, 63I, 633 .

'Russell v. Scott (1828, N. Y.) 9 Cowen 279.

- Pease v. Ditto (Igor) 189 Ill. 456,59 N. E. 983.

- See Bingham (I915) I3 MICH. L. REv. 632, 633; Salmond, Jurisprudence, Sea ro4. 
Roman law several possession was allowed only to a person who claimed to be the owner.

The element of claim of title as a requisite to legal possession is apparently overlooked by the Wisconsin court. ${ }^{10}$ During the temporary absence of the plaintiff's husband, the defendant committed a trespass in the husband's house. It was held that the wife had sufficient possession, she being by the absence of her husband in exclusive occupation of the premises, to maintain an action of trespass. ${ }^{11}$ The court overlooks the point that occupancy and residence are not possession, unless the occupancy is under claim of title of some sort. The case of the wife would seem to be like that of a servant or licensee or guest. The presumption is that the joint occupancy of husband and wife is the possession of the husband, although this may be rebutted. ${ }^{12}$

We come now to discuss the extent of the claim of title required in adverse possession. It is said in some cases, that the occupant must claim to be absolute owner in fee before he can acquire title under the statute of limitations, and further, that the claim of title must be asserted against the world. ${ }^{13}$

This question of claim of title against the world is put to the test where the occupant recognizes a paramount title in the government. Suppose that A. enters into possession of land, supposing it to belong to the United States, with the expectation of acquiring title under the Federal land laws; in fact the land has already been patented by the government to B. After A. has been in nossession for the period of the statute of limitations he seeks to have his title quieted and B. seeks to recover possession. It is held in some cases that this holding without claim of paramount title against the world does not constitute possession adverse as against the true owner. ${ }^{14}$ It is held by the weight of authority, however, that the claim of title may be adverse as against the true owner, although not hostile to the government. ${ }^{15}$ Thus possession need not be adverse to the whole world, but only as against the plaintiff who is asserting title. ${ }^{16}$ The adverse possessor

\footnotetext{
${ }^{20}$ Bieri v. Fonger (Ig09) I39 Wis. I50, I20 N. W. 863.

$"$ See, also, Ford v. Schliessman (1900) Io7 Wis. $479,485,83$ N. W. 76r, I4 HARV. L. REV. 389.

${ }^{12}$ Collins v. Lynch (I893) I57 Pa. 245, 27 Atl. 72I.

${ }^{13}$ Bedell v. Shaw (1874) 59 N. Y. 46; Ashford v. Ashford (1902) 136 Ala. 631, 34 So. 10; Harden v. Watson (I9I2) 104 Ark. 64I, I48 S. W. 506; 2 C. J. I29, note 88 .

"Hunnewell v. Burchett (1899) I52 Mo. 6II, 54 S. W. 487 . Skanski v. Novack (Igr5) 84 Wash. 39, 146 Pac. I60. See, also, cases cited in $2 C$. J. I30, note 99.

"Boe v. Arnold (1909) 54 Ore. 52, 102 Pac. 290, 20 Ann Cas. 533; Smith v. Jones (1910) 103 Tex. 632, 132 S. W. 469; Maas v. Burdetzk (I904) 93 Minn. 295, IoI N. W. I82; Iowa R. Co. v. Blumer (1906) 206 U. S. 482, 27 Sup. Ct. 759, S. C. (1905) 129 Iowa 32, 105 N. W. 342.

"Harvey v. Hollis (Ig08) I60 Fed. 53I; Skipwith v. Martin (1887) 50 Ark. 14r, 6 S. W. 514, 518; Mather v. Walsh (1804) 107 Mo. 121, I7 S. W. 755;
} 
may by error admit an interest or title in some third party while disputing the title of the true owner. ${ }^{17}$ The adverse character of one's possession is not necessarily destroyed by accepting a lease from a third party. ${ }^{18}$

We may now inquire whether the claim of title must be in fee. It is laid down in a number of decisions that the claim must be of the entire title and not simply of part of it. ${ }^{19}$ It would seem, however, that this supposed rule is clearly erroneous uinless it means merely that possession under a claim of a less estate will not be adverse to the fee is so far as it is held in subordination thereto. ${ }^{20} \mathrm{~A}$ claim for a term of years under a lease, of course, concedes that there is an outstanding title in the person under whom the lessee holds. ${ }^{21}$ The claim of a less estate than a fee may however be adverse to the extent of such claim and establish title pro tanto, as for example, the claim of a public square by a city, the fee of which is recognized to be in another. ${ }^{22}$ In Long Island $R$. Co. $v$. Mulry, ${ }^{23}$ a railroad acquired a strip of land for its road bed under condemnation proceedings, which were void as to some of the owners who were not made parties. Title was claimed under the order of the court, and the railroad used part of the premises under this claim of title for ro years. It was held that this user of the land for such a period of time established title in the railroad to a permanent easement in the land to use it for railroad purposes. ${ }^{24}$ If one claims title adversely under a void lease, he cannot be ousted until the end of the term which the lease purported to give. ${ }^{25}$

Adverse possession thus differs from disseisin in the kind of estate

Contra, McNaught Collins Co. v. May (1909) 52 Wash. 632, ror Pac. 237. See, also, Liddon v. Hodnett (I886) 22 Fla. 422, 462, 466.

${ }^{27}$ (I905) I8 HaRv. L. Rev. 380; (1906) 19 ibid. 463.

${ }^{2}$ Mitchell v. McShane Lumber McShane Co. (IgI5, C. C. A. $5^{\text {th }}$ ) 220 Fed. 878, (IgI5) I3 Mich. L. REv. 690.

${ }^{10}$ Bedell v. Shaw (1874) 59 IT. Y. 46; McLair v. Bird (rgro, Sup. Ct. Spec. T.) I20 N. Y. Supp. 1032, 1034; De Bernardi v. McElroy (1891) 110 Mo. 650, 659; Ig S. W. 626, 628; Harden v. Watson (Ig12) ro4 Ark. 641, 148 S. W. 506. See, also, 2 C. $J$. I39, 188.

${ }^{\infty}$ Howard v. Howard (1854, N. Y. Sup. Ct.) I7 Barb. 663; Wilklow v. Lane (1860, N. Y. Sup. Ct.) 37 Barb. 244; Jackson v. Johnson (1825, N. Y.) 5 Cowen, 74, I5 Am. Dec. 433, 438, 2 C. J. I29, note 93 .

${ }_{21}$ Iona $v$. U⿱t $U_{4 h}$ (1905) I6 Hawaii, 432.

$=$ La Crosse v. Cameron ( 1897 ) 80 Fed. 264,$272 ; \cdot$ Ricard v. Williams, supra.

${ }^{23}$ (I914) 212 N. Y. 108, 105 N. E. 806; 63 PA. L. REV., I44.

${ }^{24}$ Cf. Smith v. Reich (I894, Sup. Ct. Gen. T.) 30 N. Y. Supp. 167; Doherty v. Matsell (1890) r99 N. Y., 646, 23 N. E. 994; Kelly v. Kremm (1912, Sup. Ct. Spec. T.) 138 N. Y. Supp. 626, 629 .

${ }^{25}$ Warren Co. v. Lamkin (I909) 93 Miss. 123, 46 So. 479,22 L. R. A. (N. S.) 920; Tichborne v. Wier (I892) 67 L. T. 735; O'Conner v. Foley [1905] I Ir. I. Compare Sanders v. Riedlinger (1896, Sup. Ct. Tr1. 'T.) I9 N. Y. Misc. 289. 
which must be claimed. To constitute disseisin there must be (I) a wrongful entry, and (2) a claim of a freehold estate. ${ }^{28}$ In adverse possession there may be a lawful entry in the beginning which later becomes hostile and adverse, and there need not be a claim of freehold estate.

We may now mention the effect of mistake on the claim of title of the adverse holder. If a person through mistake occupies up to a certain fence or other line beyond his actual boundary, believing it to be the true boundary, this belief may qualify the adverse character of his holding and make his claim tentative. He may have no intention to claim title unless the actual line is the true line. In some jurisdictions, indeed, the view is taken that mistaken possession is presumably adverse, and the intent to claim title is to be inferred from the fact of possession. $^{27}$ It the occupier exercises dominion to a fixed visible boundary, such acts manifest a claim of title hostile, adverse and absolute, though based an a false assumption. ${ }^{28}$ The objective and physical transactions supersede inquiry into subjective mistakes and suppositions, which would be unsatisfactory in view of the policy of automatically quieting titles by tangible evidence of visible possession.

A majority of decisions, however, make intention to claim title the test. The evidence of intention must be gathered from an interpretation of the general circumstances. Uncertainty as to boundary indicates a tentative location conditional on the supposition that the fence is the true line. If there is an absolute claim of title, this is not affected by what the holder might or might not have claimed had he known that he was mistaken. But if the intent is only to claim to the true line, wherever that may be, the holding is contingent and in subordination to the true title. ${ }^{29}$

An express admission of title in another, or a claim to hold as tenant at will or by license only, would render occupancy subordinate to the true owner.30 Thus a licensee who holds over after the license is terminated by operation of law, as by a conveyance of the land or by death of the licensor, does not hold adversely unless he ceases to claim

${ }^{26}$ Fort Dearborn Lodge v. Klein (1885) II5 I11. I77, I81, 3 N. E. 272.

"French v. Pearce (I83I) 8 Conn. 439.

* Searles v. De Ladson (1908) 8I Conn. I33, 70 Atl. 589; Mielke v. Dodge (1908) 135 Wis. 388, II5 N. W. I099; Ovig v. Morrison (I910) I42 Wis. 243, 248, 125 N. W. 449.

${ }^{2}$ Preble v. Main Central Railroad Co. (1893) 85 Me. 260, 27 Atl. I49; Edwards v. Fleming (IgII) 85 Kan. 653, II2 Pal. 836, 33 L. R. A. (N. S.) 923 ; Keller v. Harrison (I9II) $15 \mathrm{I}$ Ia. 320 , I28 N. W. 85I, Ann. Cas. I913 A, 300, citing Grube v. Wells (I87I) 34 Iowa, 148 ; Carroll v. Rabberman (I909) 240111. 450, 452, 88 N. E. 995; Wiess v. Goodhue (1907) 46 Tex. Civ. App. 142, 102 S. W. 793; 2 C. J. Adverse Possession, 139, sec. 243, 245.

${ }^{30}$ Feller v. Lee (1909) 225 Mo. 319, 327, I24 S. W. I129; Clarke v. Courtney (183r, U. S.) 5 Pet. 319; 2 C. J., Adverse Possession, 127, 128. 
under the license and begins to claim in his own right as owner. The fact that he may remain wrongfully in possession for twenty years, at all times liable to an action of trespass or ejectment, will not bar the true owner or establish a title by adverse possession. ${ }^{81}$ The mistaken belief as to the existence of the license, and the claim to hold under the permission originally given, limit the claim of title. The occupancy of the wrong-doer claiming only as licensee is the possession of the true owner.

\section{II. "ESTOPPEL" OF ONE WHO CLATMS TITLE UNDER AN INSTRU- MENT PURPORTING TO CREATE SUCCESSIVE ESTATES.}

Perhaps the most curious and difficult problem that the student encounters in his study of title by adverse possession may be shortly stated as follows: Does adverse possession by one claiming a life estate under an instrument limiting successive estates enure to the benefit of those in remainder?32

There are two divergent lines of English cases on the question whether adverse possession by A., who holds under a deed or will which purports to create a life estate in him, with remainders over to $B$. and C., will enure to the benefit of the remaindermen, B. and C. The distinction between these lines of cases, although probably sound, has not been satisfactorily explained by courts or text writers, and is apparently not understood or applied in the few American cases which have thus far arisen on this question. It is believed that a satisfactory solution can and must be found, without invoking that much abused solvent, "estoppel", as the English cases do.

The problem to be solved is complex, and may best be stated in the form of four supposititious cases, slightly variant, which will afford the studious reader a pleasant exercise in legal analysis. While this problem is not one which is apt to arise frequently, the student who masters it will gain in the power of applying the fundamental principles underlying the law of adverse possession.

I. A. B. has been in possession of Whiteacre for five years adversely to C. D., the true owner. He makes a deed good in form to $X$. for life, remainder to $Y$. for life, remainder to $Z$. in fee. A. B. delivers possession to $X$. and he holds for five years more, when he dies. A ten year statute of limitations is in force. After the death of X., leaving an heir P., C. D. re-enters. Both P. and Y. bring ejectment against $C$. $D$.

${ }^{31}$ Bond v. O'Gara (1900) 177 Mass. 139, 58 N. E., 275.

2 This problem is particularly suggested by the cases of Dalton v. Fitzgerald, [1897] I Ch. 440, s. c. [1897] 2 Ch. 86, 3 Gray, Cases on Property (2d ed.) 43; and Hanson v. Johnson (1883) $62 \mathrm{Md}$. 25, 40 Am. Rep. I99, Aigler, Cases on Titles, 68. 
2. Suppose A. B.'s deed had no seal, or was invalid because of the grantor's incapacity or for any other reason, would the result be different from above case where the deed is valid to convey whatever possessory title A. B. has?

3. Suppose A. B. never had possession or title, but $X$. enters claiming under a valid deed or will as color of title and holds for ten years?

4. Suppose A. B. is lawful owner of the land, but the deed or will by which he purported to transfer to $\mathrm{X}$., Y. and $\mathrm{Z}$. was invalid by reason of informality or incapacity. $X$. holds under it for ten years.

Two issues arise in these four cases: (I) Does the adverse possession by $\mathrm{X}$., a person claiming title under an instrument purporting to give him only a life estate, if continued for the statutory period, bar and destroy the entire title and estate of C. D., the true owner, or does it only give X. a life estate; (2) if C. D., the true owner, is barred, does $X$., the adverse holder under such instrument, acquire the fee for himself, his heirs, and assigns, or are he and his heirs "estopped" to deny the title of $\mathrm{Y}$. and $\mathrm{Z}$. who are given future estates by the instrument under which he claimed?

In case I it seems clear that C. D., the true owner, will be barred in ten years. In Charles $v$. Pickens, ${ }^{33}$ the creator of a life estate by grant did not have a perfect title, but had only held the land in adverse possession which had not continued long enough to establish a perfect indefeasible title. It was adjudged that one claiming as remainderman under a will or deed may tack to his own possession the possession of the testator and the life tenant under the instrument.

The possession of the life tenant $X$. here enures to the benefit of the remainderman $Y$. The possession of the grantor is the common source of their title, and the adverse possession which he initiated continues to run in Y's favor. Where one in adverse possession, with an inchoate possessory title, carves this up into successive estates by limitations in a will or deed, the transfer is valid and effective against all those claiming under the possessory title. This may be perfected by the statute against those claiming under the true title. The rights of those claiming under the prior adverse possessor remain inter se as regulated by the will or deed. Y. can trace his title back to the adverse possession of A. B. This possession of A. B. has been continued by $X$. until the period has run. P., the heir of X., inherits nothing. Clearly he cannot dispute the title of the remainderman, which goes back by a valid conveyance to the same source of title as that of his own ancestor. It is in this sense that he is "estopped" to. deny the title of the remainderman. ${ }^{34}$

" (I908) 214 Mo. 212, 112 S. W. 551, 24 L. R. A. (N. S.) 1055.

"Asher v. Whitlock (I865) L. R. I Q. B. I; Hazwsbee v. Hawksbee (1853, Eng. V.-C.) II Hare, 230; Haynes v. Boardman (1875) IIg Mass. 414; cf. 
In case 2 , on the other hand, where A. B.'s deed had no seal, or was invalid for incapacity, informality, misdescription, or any other reason, the result would be different. $Y$. and $Z$. can derive no benefit from the adverse possession either of A. B. or X. The reason is that they do not connect with $A$. B. as a source of title. There is sufficient privity between A. B. and X. in spite of the defective instrument, by reason of the de facto delivery of possession. But there is no reason why their adverse possession should enure to the benefit of $Y$. and $Z$.

It is, indeed, contended in some cases, that here also, $X$., the ostensible life tenant, should be "estopped" to deny that his possession enures to the benefit of whose in whom the deed or will purported to invest the remainder. In Anderson v. Rhodus, ${ }^{35}$ a South Carolina case, it was held that, where under an unsealed instrument purporting to convey lands to one for life with remainders over, R., the tenant for life, holds long enough to acquire title by adverse possession, he cannot question the title of the remaindermen, his possession enuring to their benefit as well as his own. It is said that the possession of $R$. was not hostile to the children in remainder, but was in assertion and support of their common title. Accordingly it must enure to sustain that title and the instrument creating it. There are several American, Irish and Canadian cases to this effect which, however, fail to observe the distinction drawn by the English cases which we are attempting to expound. ${ }^{38}$ There was, indeed, a dictum in the English case of Anstee v. Nelms ${ }^{37}$ that if M. M., a person to whom an estate for life is given by will, takes possession and holds as part of the devised farm a piece of land not described in the will, that he cannot set up a title as gained by adverse possession against the remainderman, so as to be able to transmit title to his heir. Urder the facts of the case, the land passed by the will, but the dictum is error, as later English cases show that M. M.'s possession would enure to the benefit of the remainderman only if the will were operative.

There is now established in the English decisions a distinction between the case where the testator or grantor has an incomplete possessory title and actually transfers that, and cases where he has a title, whether absolute or possessory, but does not make an effectual transfer. In the former class those given limited estates are governed by the will or deed, as the instrument is really operative on the title

Austin v. Rutland R. Co. (1873) 45 Vt. 215, 236; Reynolds v. Trawick (1918, Ala.) 78 So. 827 ; Roberts v. Cox (1913) 259 Ill. 232, I02 N. E. 204. See also, Creation of Limited Estates by Possession (1896) 4I Sor. Jour. ReP. 448.

* Anderson v. Rhodus (1860, S. C.) 12 Rich. Eq. 104, 109.

${ }^{86}$ Brown v. Brown (1884) 82 Tenn. (I4 Lea.) 253; Kernaghan v. MciNally (186r) 12 Ir. Ch. 89, 130; Moloney v. Moloney [1894] 2 Ir. 1, 6; Conners v. Mygatt (Igr5, N. S.) 24 Dom. Law Rep. 537,47 N. S. R. I39.

${ }^{87}$ (I856, Ex.) I H. \& N. 225. 
which is later perfected. It is otherwise where the instrument is altogether inoperative. A person entering on the property then takes no interest by virtue of the instrument under which he claims, and those claiming future estates thereunder obtain no interest. Although he may be named in the instrument as tenant for life, his possession is independent of the instrument and does not enure to the benefit of those in remainder. ${ }^{38}$

Thus in cases 2 and 4 , where the deed or will is void or inoperative to pass any title, the liie tenant or his heirs can say, when called on to relinquish possession by those claiming in remainder under such instrument, "You have no title to turn me out." But if the grantee or devisee in remainder derive even a possessory title by virtue of a valid (or even a voidable)' will or deed, the life tenant's heirs or assigns cannot hold against them, even though there was a defect. in the title of the testator or grantor. So in case 4 where the grantor or testator has good title, the supposed life tenant under the void instrument is not bound to refer his possession to the instrument. Neither he nor the remainderman get any rights under it, and there is no reason why he or his heirs should be "estopped" to set this up. His adversepossession is hostile to any title in the grantor or testator, and bars the true owner, but it does not operate to validate the void instrument: The supposed remaindermen have nothing to be barred, so the rule that a life tenant cannot hold adversely to the remainderman does not apply. There never were any remaindermen. To show title they would have to rely on the alleged will or deed. So in case 3 , the supposed life tenant derives nothing from the will or deed even though valid in form as the grantor or testator has nothing to give. In cases 2,3 and 4 , then, there is no basis for the so-called doctrine of estoppel.

These different alternatives thus present the problem of the effect of adverse possession of one claiming title to a limited estate, (I) under a will or deed valid in form by a grantor or testator with defective title, but in adverse possession; (2) under a deed or will void or invalid per se owing to informality, illegality, defective description, or lack of capacity by a grantor or testator so possessed; (3) under a deed or will valid in form by grantor or testator who never had either title or adverse possession; and (4) under a deed or will invalid per se made by a grantor or testator who was the lawful owner of the property and in possession.

This latter situation is illustrated in the case of Hanson $v$. Johnson. ${ }^{39}$ This was an action of ejectment by the heirs at law of Mrs Wroth

*Dalton v. Fitzgerald [1897] I Ch. 440, 2 Ch. 87; Re Anderson [1905], 2 Ch. 70; Paine v. Jones (1874, Eng.) L. R. I8 Eq. 320; Smith v. Smith (I884) 5 Ont. R. 690 ; Re Stringer's Estate (1877) 6 Ch. D. I, ro. See Lightwood, Time Limit on Actions, 13I, I9 Halsbury, Laws Eng. 158, 13 ibid. 374.

(1884) 62 Md. 25, 50 Am. Rep. 199, Aigler, Cases on Titles, 68. 
suing for an undivided half interest in a tract of land of which she died seized. Mrs. Wroth died December, 1854, leaving a paper purporting to be a will, by which she devised the farm to her husband, P. Wroth, for life with remainder in fee to her nephew, George Hanson.

The will was not executed in due form to pass real estate as required by the Maryland statute then in force, because the written consent of the husband was not annexed thereto, and also because it was not executed sixty days before her death. The will was, however, admitted to probate. Under it the husband, P. Wroth, entered into possession of the farm on January I, I855, claiming title as tenant for life. The farm was enclosed and under cultivation and the possession was actual, visible, and notorious. Wroth continued in possession from January I, I855, to February 5, I868, a period of over thirteen years, when he united with the remainderman, Hanson, in a conveyance to Johnson. Johnson entered and continued in possession up to the commencement of the suit in April 1882, a period of fourteen years. The statute ${ }^{40}$ which provides that no one shall make an entry into any land but within twenty years after his right shall accrue was in force in Maryland.

The plaintiffs, as the heirs at law of Mrs. Wroth, had the legal title, unless their right was barred by the adverse possession of defendant Johnson tacked to that of Wroth under whom he claims. The remainderman Hanson having joined in the deed with Wroth to Johnson conveyed whatever claim he had under the invalid will.

It was held that the possession of Wroth (I) was adverse and (2) enured to the benefit of the remainderman Hanson; "his possession was in law the possession of the remainderman, and as such it represented the entire estate, his own estate for life, and the estate of George A. Hanson in remainder. . . . The will was, it is true, invalid, but Dr. Wroth having entered into possession, claiming title under it, he would be estopped from denying the title of the remainderman claiming under the same instrument. This was decided in Board $v$. Board."'41

The court was in error on this point. The case of Board v. Board would not be applicable to the situation that appeared here, as the will was valid in that case, and the Maryland court failed to apprehend the distinction drawn in the English cases. In Board v. Board, a testator who was simply tenant by the curtesy of certain premises, undertook to devise them for life to his daughter Rebecca, with remainder to his grandson, W. by a will valid in form. Upon the death of the testator, Rebecca, the daughter, the would-be life tenant, entered and held possession for more than twenty years and then con-

2I Jac. I. ch. 16.

(1874) L. R. 9 Q. B. 48. 
veyed the property in fee to the defendant. In the meantime, the grandson, W., sold his supposed reversionary interest to the plaintiff, and upon the death of the daughter, Rebecca, he brought an action of ejectment. It was held that Rebecca, having entered under the will, the defendant claiming under her was estopped as against all those in remainder from disputing the "validity of the will," (or rather the title of the plaintiff derived from the same source as his own). The plaintiff accordingly recovered possession.

Blackburn, J., says: "The case is like that of a tenant coming in under a landlord: he is estopped from denying his landlord's title."

Mellor, J., says: "A person cannot say that a will is valid to enable him to take a benefit under it, but invalid so far as regards the interests of those in remainder, who claim under the same will."

The difference between Board v. Board and Hanson v. Johnson, supra is this:-that in Board v. Board, the will was valid to transmit whatever title the testator had. It passed that possessory title to the extent of a life estate therein to Rebecca; but William, the remainderman, under the same will shows a better right to possession after her death. The validity of the will does not rest upon estoppel. It is valid per se, except for the defect of the testator's title, and where two parties both go back to the same source of title, that one prevails who can show that he connects with it. Where the instrument is valid to transmit a possessory title, the remainderman can show a better connection with the common source of title. The English case was similar to problem No. I, namely, a valid will by a testator without title, but with possession, the life estate being ended, while the American case was that of problem No. 4, namely, a void will by one having legal title.

In Hanson $v$. Johnson there is continuity of adverse possession between $P$. Wroth and Johnson for twenty years, but there is no continuity of claim of title between them, except as to a life estate, unless $P$. Wroth can be regarded as in effect claiming a fee as against the heirs of Mrs. Wroth.

Taking the English view, that the holding of the life tenant Wroth under the invalid will did not enure to the benefit of the remainderman Hanson, how is it that the possession by a person claiming only a life estate destroys the fee of the heirs or person really entitled?

It is true that where an estate claimed by $X$. is an estate for life, his possession under such claim could not be availed of in support of Johnson's claim in fee. ${ }^{42}$ But as against the heirs of Mrs. Wroth, $P$. Wroth was asserting a hostile claim in fee, even though he had an erroneous idea that Hanson was entitled in remainder. Declarations by a person in possession that he holds for others, will not prevent

- Kelly v. Krem (1912) I38 N. Y. Supp. 626, 629, 78 N. Y. Misc. Rep. 576; Ricard v. Williams, supra. 
him from setting up title in himself, if he shows that this recognition was based on misapprehension."3 Such are the cases of adverse possession of land supposed to belong to the public domain.4.

The result in Hanson $v$. Johnson may, therefore, be sustained, although the reason given by the court, that the possession of the life tenant enured to the benefit of the remainderman by estoppel, was erroneous. Defendant Johnson got nothing by the conveyance from the remainderman Hanson. The heirs of Mrs. Wroth were barred because Wroth's claim of title was exclusive, hostile and adverse as to them and inconsistent with their fee.

In the recent Alabama case of Reynolds $v$. Trazeick ${ }^{45}$ the case of Hanson $v$. Johnson is cited for the proposition that, where one in adverse possession conveys to $A$. for life, remainder to $B$., the possession of the tenant enures conclusively by way of estoppel to the benefit of those in whom the deed undertook to invest the remainder. This case was correctly decided, however, as the deed was a valid conveyance to transfer the possessory title. The situation was entirely different from that in Hanson $v$. Johnson, where the will was invalid. The court evidently was not familiar with the distinction between these cases.

An English case parallel to Hanson $v$. Johnson is represented by Paine $v$. Jones. ${ }^{38}$ There a testator by his will which took effect prior to the Wills Act, devised all his real estate and also all his other estate of which he might be possessed at the time of his death, in trust for his wife for life with remainders over. After the date of his will he purchased a freehold estate. On his death his widow entered into possession of the after-acquired property as well as of the devised estate, believing that all the property passed by the will. She continued in possession for over 20 years, claiming under the will a life estate, and it was held that she acquired a good title in fee by adverse possession as against the remainderman. She was not precluded (estopped) from setting up that, according to the law as it then stood, the will did not pass the after-acquired property to the remainderman, since neither she nor the remainderman took any title to it under the will. As Malins, V. C., says: "Under this will the widow had no title whatever." A bill was filed by the remainderman to oust the purchaser from the widow. His only title was under the will, and the will as a conveyance was inoperative. The defendant was, therefore, not estopped from saying as against the remainderman that the devise was invalid.

\footnotetext{
aright v. Stice (I898) I73 Ill. 57I, 580, 5I N. E. 7I; Brittain v. Daniels (r886) 94 N. C. $78 \mathrm{r}$.

"See note 15 , supra.

(1918, Ala.) 78 So. 827 .

(1874, Eng.) I. R. 18 Eq. 320.
} 
In re Stringer's Estatet7 presents a similar holding with an acute discussion by Jessel, M. R. The will of Stringer was void. A., named as life tenant, having no title, entered claiming as tenant for life and held for the statutory period. B., the supposed remainderman, who had no title either, sues A.'s devisee in ejectment. The principle of estoppel was held not to extend to cases where the defect was not in the devisor's title but in the will itself-that being invalid or illegal. Jessel, M. R., says:

"Another class of cases, of which several instances were referred to, is this: A man is in possession of land with a defective title, but he has possession. He devises to a man for life with remainder over. The devisee, having no title except under the will, enters under the will. It has been held that he cannot deny that the testator had a right to devise in the way he has devised; that is, that the testator had a sufficient title to support the devise as far as the devisee is concerned-not to make the devises valid which were invalid because the devises were invalid per se if the testator had insufficient title. [Problem $x$, supra.]

"Therefore the whole of the estoppel is this: you have entered under the will of a man who had possession; as far as you are concerned possession is the fee: you cannot say, you having no title, that he had'less than the fee which he purported to devise. You are estopped from denying his title to dispose of that fee, though you may have found out afterwards that he was only tenant for years, or tenant from year to year, or tenant for life, or anything else. You have got possession under that will, and possession in law, as far as you are concerned, of the fee.

"And now we come to a suggested third extension, and that is this: A man enters under a will which contains an invalid devise. It is alleged that by claiming under that will and getting possession he affirms the invalid devise. Now, I cannot see the distinction suggested between the case where the remainder is invalid as well as the tenancy for life, and the case where the remainder alone is invalid. If he enters rightfully as tenant for life, and the next remainder is invalid, it is admitted that will not make the remainder valid, because he had only a right to his tenancy for life; but he only claims as tenant for life; he admits throughout that he is tenant for life, and he pays charges as tenant for life. He enters not upon the ground that he admits the title of the remainderman, but upon the ground that he claim as tenant for life.

"But if he himself enters without title, it is said that because he has no title himself his entry gives a new title to the remainderman. I cannot see it. Suppose the defect in the tenancy for life is a different defect from that of the remainderman: suppose the gift to him was void for remoteness, and the gift to the remainderman was void as being to a charity, or vice versa. How can it be said that his entry, though wrongful as tenant for life, estops him from doing anything? Why cannot he set up the defect against the remainderman? Can it make any difference if it happens to be the same defect? Why can he not admit the defect, and say, 'I find now I have no claim to the

" (1877) 6 Ch. D. I, Iо. 
property?' It does not appear to me to be within the doctrine of estoppel at all; neither within the principle of the doctrine, nor within the authorities which established the doctrine; and all I can say is, if the doctrine is to be extended, it must be by some other court and not by me."

In re Anderson ${ }^{48}$ also followed Paine v. Jones, holding that $\mathrm{W}$. and those claiming under him were not estopped by W.'s entry as tenant for life, under a void testamentary disposition by $F$. from asserting as against $P$., the remainderman, that the will was invalid for incapacity.

The case of Dalton v. Fitzgerald ${ }^{49}$ recognizes, in a blinking uncomprehending manner, the distinction between problems $I$ and 2 . The Chancery Division and also the Court of Appeal hold that where a grantor who has no title (but adverse possession?) purports to convey by a valid instrument a piece of land to $A$. for life, with remainder over to B. and C., and A. enters on the land under the deed and holds for the period of limitation against the true owner, that $A$. is estopped against the remaindermen from disputing their title. The court cites and relies upon the doctrine of Board v. Board: that where a possessor who has only a limited or defective title, conveys or devises the property to several persons in succession by limitations which would be good and valid in law if the grantor or devisor had a perfect title, the limited owner who enters under the transfer cannot contest the title of the other transferees derived from the same source as his own. Apparently the court could not understand the other line of cases represented by Paine v. Jones and Re Stringer's Estate, supra.

The material facts of Dalton v. Fitzgerald are as follows. Under the mistaken impression that lands in the township of Bulk passed by John Dalton's will, the trustees under the will made a settlement in pursuance of the will purporting to cover these lands in addition to other lands, and conveyed them to the use of testator's daughters, with remainder to the use of Sir James Fitzgerald for life, with remainder to Sir Gerald Fitzgerald for life, with remainder to the plaintiff for life, with divers remainders over. James Fitzgerald entered the lands and died. Gerald Fitzgerald entered under the settlement, held for the statutory period, and died, leaving plaintiff next in line. Gerald Fitzgerald, it appeared, had himself registered as owner in fee and devised the lands to the defendants, who entered. The defendants claimed Fitzgerald had acquired a fee. Plaintiff claims as remainderman under the settlement, which was invalid for lack of title in the grantors.

It was held that Sir Gerald having entered under the deed, acquired a good title by adverse possession against the rightful owners,. John

- [1905] 2 Ch. 70.

[I897] I Ch. 440 , s. c. (C. A.) [1897] 2 Ch: 86, 3 Gray, Cases on Property (2d ed.) 43 . 
Dalton's heirs, but he was estopped from denying the rights of the others under the settlement.

The true foundation of the so-called "estoppel" is the fact that at least a possessory title passes by deed or will. The validity of the instrument and the fact that it is operative can be material only in case something is to pass under it, such as possession. "Estoppel" would be the same from the mere fact of claiming only a life estate, whether the instrument were operative or inoperative.

In the report of the case of Dalton $v$. Fitzgerald the material fact is not disclosed whether the grantors, the trustees, took possession of the lands prior to making the deed. Accordingly it is impossible to say whether the case is correctly decided or whether it should not be classed under problem 3. If the life tenant, Fitzgerald, did not go back to the trustees as his source of title, but initiated a possession of his own, there seems to be no reason why his possession should make a worthless deed (from grantors with no title or possession) convey title to those in remainder, when he himself got no benefit or title under the deed, but solely by his own independent adverse possession. If, however, the grantors had had possession, and their deed was a good deed in itself, A., the life tenant, and his successors cannot dispute that the remaindermen have a superior title derived from $X$. as they go back to a prior possession which $A$. received from $X$. A's holding has not been adverse to them and could not be. This result is not based on estoppel but on the ordinary fundamental proposition that he prevails who can trace his title back to the prior possession.

In re Tennent's Estate ${ }^{50}$ also recognized the distinction between problems I and 2. The Irish Court here held that a supposed life tenant under an invalid will which purported to be an exercise of power to appoint lands, is not estopped from saying as against the remainderman that the devise over to him is void as being an invalid exercise of the power of appointment. The life tenant by entering under the defective will is not prevented from setting up the invalidity of the limitations over, and is held to acquire title as against everyone although claiming only as tenant for life under the will.

The question involved in these cases is ably and acutely discussed in the dissenting opinion of Freeman, J., in the Tennessee case of Brown v. Browm. ${ }^{51}$. That case raises the question as to what is the effect in establishing the title of the supposed-remainderman of the holding of one who claims as tenant for life under an invalid will, voidable by the heirs for fraud or undue influence.

By the supposed will of Benjamin Brown only a life estate was given to his widow. She went into possession under this invalid will and claimed according to its terms. The parties claiming the remain-

${ }^{50}$ [ï13] I Ir. 280.

${ }^{31}$ ( I884) 82 Tenn. ( 14 Lea) $253,268$. 
der interest were never in possession at all. It was urged that the holding of the widow, as a life tenant, enured to the benefit of the remaindermen and perfected their title as well as her own, and the majority of the court, per Cooper, J., sustained this contention, on the ground that the tenant for life represented the remaindermen in fee, her possession being also the possession of those having other interests carved out of the fee by the assurance which she held, citing the case of Hanson v. Johnson, supra. The decision may be sustained on the ground that the will was not void, but only voidable by the heirs by suit to recover the property. If the will had been void, as it seems to have been in Hanson v. Johnson as to the real estate, so as to pass no title, then the arguments of Freeman, J., dissenting, should have prevailed.

Freeman, J., dissenting, argues that the adverse possession of the life tenant cannot enure in favor of parties not in possession, and for whom in fact she did not hold under the voidable muniment of title. The Statute of Limitations cannot confer a title on anyone except the persons in adverse possession, actual or constructive, and so if possession be held under a void deed or will, the holding will not establish the limitations or remainders created by the deed or will.

To acquire title by adverse possession there must be continuous adverse possession plus claim of title or interest in the property against the true owner. The law does not enlarge the estate or title claimed. How can the possession of the life tenant, holding for himself or herself alone, silently work for the remainderman to perfect his title? The party entitled to the benefit of the statute, in general, is the party having possession, either by himself or by those through whom he claims according to the extent of his claim of title. The remaindermen do not claim through the life tenant but after him.

The remaindermen must, therefore, stand on their title derived from the will which ex-hypothesi is invalid. Having had no possession under the will, the fee claimed by them is not aided by the possession of another who did not claim the fee for them. Her possession was not their possession. It is true that the possession of a tenant for life is usually the possession also of the remainderman. But that is so where there has been an estate in remainder created. ${ }^{52}$ Can the true owners be ousted of a valid title when they have had no right of action against the parties acquiring the title, or anyone holding for them, by which their claim could be adjudged? Why should it matter whether the life estate and remainder are conveyed by the same instrument or by different instruments when the remainderman does not claim through the life tenant? The life estate may be a good title against the owner of the fee while the remainder may be void. Would this lawful possession be effective in favor of a void remainder after a valid life estate? If the possession of the life tenant is the possession

Bomar v. Stepherus (1848 Tenn.) 9 Humph. 546; Doe v. Reade (I807, K. B.) 8 East, 353; 2 Preston, Abstracts, 293, 295. 
of the remainderman under the same instrument, it would be so; yet no right of action would exist, and the owner would be barred by the possession of a party he could not dispossess. This argument of Freeman, J. is the same as that used by Jessel, M. R. in Re Stringer's Estate supra.

The statute only works to perfect the title of the party in possession either by himself or by one holding the possession for him, as in the case of a tenant holding for his landlord. But where land not included in a lease was taken possession of by the tenant as supposedly included in the lease, it was held that the lessee who occupies land beyond the boundaries described does not acquire title for his landlord as his possession is not that of the lessor. ${ }^{\mathrm{b3}}$

In the early Tennessee case of Bomar $v$. Stephens, ${ }^{54}$ where a father held slaves under a void trust deed conveying a life estate in trust to his wife, remainder to the after-born children, it was held that the statute would vest the title in the life tenant but would not give validity to the limitations in remainder, which the deed attempted to create. It was argued that the statute can confer title on no one but the person in adverse possession, either by himself, or by one holding the possession for him. "It cannot be said that the possession of a party actually holding a slave is the possession of another person in remainder in whom no estate in remainder has been created."

We may conclude that the American courts should recognize the distinction of the English cases which we have discussed with reference to the creation of successive estates by adverse possession. The distinction in brief is between the effect of claim of title under (I) a devise or grant valid as a conveyance of a defective or possessory title, and (2) under a devise or grant invalid as an instrument of conveyance, whether the settlors' title is absolute or possessory. In the first case the adverse possession was initated by the settlor and the life tenant's continuance of that possession does. not give him title against the remainderman in the valid deed or will. Title is established for the benefit of all deriving interests under the same source of title. In the second case the supposed life tenant's adverse possession may give him a good title against the whole world, including the remainderman. This is loosely expressed by saying that in the first case there is an estoppel but not in the second. The truth is, that this is not a question of estoppel but merely an application of the rule that possession is a source of title good except against those who can connect themselves with a prior possession or title.

"Holmes v. Turners Falls Co. (1889) I50 Mass. 535, 546 (1908) 22 HARv. I. Rev. 138; Bayne v. Brown (IgII) 60 Ore. Iro, I18 Pac. 283; Magdalen Hospital v. Knotts (1879, H. L.) 4 App. Cas. 324, 336; Tabor v. Godfrey (1895) 64 L. J. Q. B. 245; Kingsmill v. Millard (1855) Ir Exch. 313; I8 Halsbury, Laws of Eng., Landlord $\mathcal{E}$ Tenant, 562; Lightwood, Time Limit on Actions, 108.

" (1848, Tenn.) 9 Humph. 545. 